\title{
Every Forty-eight Hours
}

National Cancer Institute

\section{Source}

National Cancer Institute. Every Forty-eight Hours. NCI Thesaurus. Code C89790.

To be done at regular intervals of every 48 hours. 